\title{
Effect of Weed Management Practices and Establishment Techniques on Yield and Economics of Rice in North-West Himalayan Sub-Tropical Foothills
}

\author{
Jai Kumar*, Anil Kumar, B.C. Sharma, Rajeev Bharat, A.P. Singh, \\ Neetu Sharma Lobzang Stanzen and Reena
}

\author{
Advanced Centre for Rainfed Agriculture, Rakh Dhiansar, SKUAST-J, \\ Samba, J\&K -181133, India \\ *Corresponding author
}

A B S T R A C T

\section{Keywords \\ Establishment techniques, Weed management, Yield, economics.}

\section{Article Info}

Accepted: 15 October 2017 Available Online: 10 December 2017

\begin{abstract}
A field experiment was conducted in sandy loam soil having slightly alkaline in soil reaction with medium available phosphorous and potassium and low in available $\mathrm{N}$ and organic carbon during the Kharif seasons of 2006 and 2007 in factorial randomized block design with three replications to find out the effects of weed management practices and establishment techniques on yield and economics of rice. The result revealed the superiority of the treatment with respect to crop productivity where mechanical hoeing using cono-weeder twice was used as weed management practice which was statistically similar to other weed management treatments like fenoxaprop-p-ethyl (Puma super) @ $0.06 \mathrm{~kg} \mathrm{a.i} \mathrm{ha}{ }^{-1}+1 \mathrm{HW}$, metsulfuron methyl + chlorimuron ethyl (Almix) @ $0.004 \mathrm{~kg} \mathrm{a.i}$ $\mathrm{ha}^{-1}+1 \mathrm{HW}$ and fenoxaprop-p-ethyl when applied alone whereas the latter two treatments were at par with the treatment metsulfuron methyl + chlorimuron ethyl (Almix) @ 0.004 $\mathrm{kg} \mathrm{a.i} \mathrm{ha}{ }^{-1}$. Among the establishment methods of rice, statistically non-significant results were obtained with respect to grain yield, straw yield and harvest index in conventional and SRI methods of rice establishment. However, conventional method of rice showed marginally higher yield values over the SRI method of rice establishment. Mechanical hoeing with cono-weeder practised in rice proved to be superior economically as compared to all other weed management practices. Among the rice establishment methods, crop planted under conventional method registered more economic returns as compared to that planted under SRI method. Higher B:C ratio was observed with the mechanical hoeing using conoweeder twice (1.78) which was closely followed by metsulfuron methyl + chlorimuron ethyl (Almix) @ $0.004 \mathrm{~kg} \mathrm{a.i} \mathrm{ha}{ }^{-1}$ and fenoxaprop-p-ethyl (Puma super)@ $0.06 \mathrm{~kg}$ a.i ha ${ }^{-1}$.
\end{abstract}

\section{Introduction}

Profitability from rice production is considered to be less owing to high cost of cultivation and poor general productivity. Appropriate seedling age at transplanting is essential for satisfactory yield. At present, generally it is recommended to transplant 2527 day old rice seedlings (Anonymous 1997). Uphoff (2002), while emphasizing system of (SRI) technique of Fr. Henri de Laulanie, opined that early transplanting at young 
seedling age preserves plants potential for much greater tillering more root growth, and better yield. Old seedlings were found to mature later because of delayed formation of tillers and longer time to recover from transplanting shock resulting in poor yield (Makarim et al., 2002). The problem of extensive weed incidence during early stages of rice crop growth cannot be undermined which competes with crop plants for moisture, nutrients, light, space and other growth factors. This crop-weed competition leads to significant yield losses to the tune of 35-55 per cent in transplanted rice (Gautam and Mishra 1995; Purushamam 1996). Naiyar and Tajwar (2017) reported that the rice crop grown with all six principles of SRI recorded significantly higher plant height $(118.4 \mathrm{~cm})$, total tiller per meter ${ }^{2}$ (339), leaf area index (3.5) dry matter accumulation $\left(\mathrm{g} / \mathrm{m}^{2}\right)$, crop growth rate $\left(\mathrm{g} / \mathrm{m}^{2} /\right.$ day $)$, number of panicle per meter $^{2}$ (272), 1000 grain weight $(29.9 \mathrm{~g})$, Panicle length $(26.8 \mathrm{~cm})$, Panicle weight (4.6g), number of filled grains per panicle (139), number of unfilled grains per panicle (28) and improvement in grain yield and straw yield was $33.3 \%, 28.3 \%$ and $23.6 \%, 18.9 \%$ higher under all six principles of SRI compared to SRI with 21 days old seedling and conventional transplanting.

Recent estimates showed that average reduction in yield due to weeds varied from 12 to 72 per cent depending upon weed flora and the extent of competition offered by weeds to the crop. Hand weeding, though efficient yet is a costly affair. For keeping weed population under threshold level, there is a need for an evaluation of appropriate weed control methods over and above the existing practice. Hence, agronomical manipulations such as establishment techniques with appropriate weed management method may offer an effective option for better control of weeds in rice, thereby enhancing rice yield.

\section{Materials and Methods}

A field experiment was conducted at Research Farm, Division of Agronomy, Shere-Kashmir University of Agricultural Sciences and Technology of Jammu during kharif seasons of 2006 and 2007 to examine the effect of weed management practices and establishment techniques on productivity and profitability in rice. The soil of the experimental field was sandy loam in texture having a $\mathrm{pH}$ of 8.1 , low in organic carbon and nitrogen, medium in available phosphorus and potassium. The experiment was laid out in factorial randomized block design with fourteen treatment combinations, comprising of seven weed management practices viz. weedy check, weed free, metsulfuron methyl + chlorimuron ethyl (Almix) @ 0.004 kg a.i. $\mathrm{ha}^{-1}, 20$ DAT, metsulfuron methyl + chlorimuron ethyl (Almix) @ 0.004 kg a.i. ha 1, $20 \mathrm{DAT}+1 \mathrm{HW}$ at $30 \mathrm{DAT}$, fenoxaprop-pethyl (Puma Super) @ $0.06 \mathrm{~kg}$ a.i ha ${ }^{-1}, 20$ DAT, fenoxaprop-p-ethyl (Puma Super) @ $0.06 \mathrm{~kg}$ a.i ha ${ }^{-1}, 20 \mathrm{DAT}+1 \mathrm{HW}$ at $30 \mathrm{DAT}$, mechanical hoeing with cono-weeder twice(15 and 30 DAT) and two establishment methods viz., Conventional transplanting (27 days old seedling and 2-3 seedling hill ${ }^{-1}$ ) and System of rice intensification SRI (10 days old seedling and 1 seedling hill ${ }^{-1}$ ) with three replications. Two types of nurseries were raised for the rice crop. In case of conventional technique, raised beds of $10 \mathrm{x}$ $1.25 \mathrm{~m}$ were prepared with the help of tractor and spade. The seed of PC-19 variety @ 40 $\mathrm{kg} \mathrm{ha}{ }^{-1}$ was sown $10 \mathrm{~cm}$ apart in rows, whereas for raising seedlings under system of rice intensification (SRI), four raised beds of $3.0 \mathrm{~m} \times 1.25 \mathrm{~m}$ dimension were prepared by spade with a water channel of $0.5 \mathrm{~m}$ width made around consisting of alternate layers of soil and well decomposed FYM of 1.5" and 1" thickness respectively, until it was 6" above the ground level having final layer of $2.5^{\prime \prime}$ thickness. On these beds pre- germinated 
seeds@8 kg ha ${ }^{-1}$ were broadcasted and the beds were mulched for first three days to avoid bird damage. Beds of both the nurseries were irrigated frequently to maintain adequate soil moisture. Transplanting of rice crop was done manually on $7^{\text {th }}$ and $10^{\text {th }}$ of July during kharif seasons of 2006 and 2007, respectively for both the establishment techniques. In case of conventional technique, 27-28 days old seedlings and 2-3 seedlings hill ${ }^{-1}$ were planted in normal spacing of $20 \times 10 \mathrm{~cm}$ whereas in case of SRI, 10 days old seedlings were removed carefully along with soil from the nursery bed without damaging the root zone and then single seedling hill $^{-1}$ was transplanted 1-2 cm deep into the soil that is muddy but not flooded at a spacing of $25 \times 25$ $\mathrm{cm}$ on the same day of transplanting. Rice crop was grown with a uniform application of recommended NPK $\left(120 \mathrm{~kg} \mathrm{~N}, 60 \mathrm{~kg} \mathrm{P}_{2} \mathrm{O}_{5}\right.$ and $25 \mathrm{~kg} \quad \mathrm{~K}_{2} \mathrm{O} \quad \mathrm{ha}^{-1}$ ) in conventionally established plots while in SRI established crop, $25 \%$ of the recommended dose of NPK was supplied through well decomposed FYM on oven dried $\mathrm{N}$ content basis $(0.62 \%)$ and remaining amount of NPK was supplied through inorganic sources of nutrients through urea, DAP and MOP, respectively. One third amount of $\mathrm{N}$ and full dose of $\mathrm{P}$ and $\mathrm{K}$ were applied as basal dose at the time of transplanting. Remaining $\mathrm{N}$ was top dressed in two equal splits at 30 days intervals. Irrigation was applied at regular intervals in conventional method of rice establishment to keep the water standing in the plots throughout the crop season with intermittent drainage whereas in case of system of rice intensification (SRI), plots were irrigated so as to keep the soil moist and no water was allowed to stand in the plot until the crop entered the reproductive stage. After panicle initiation, a thin layer of water $(1-2 \mathrm{~cm})$ was maintained until 10-15 days before the crop was harvested. All the herbicides were applied with the help of knapsack sprayer 20 days after transplanting as per treatment.
Weed control efficiency was worked out at 60 DAT and at harvest. It was expressed as the percentage reduction in weed density due to weed management practices over control. It was calculated by using weed density per cent in control and treated plots (Mani et al., 1973).

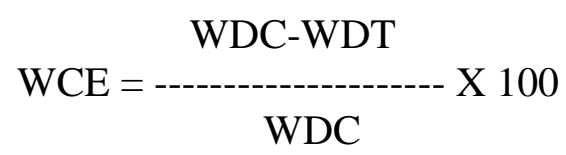

Where:

WCE: Weed control efficiency

WDC: Weed dry matter in control

WDT: Weed dry matter in treatment

Weed index (WI) was worked out by using grain yield of weed free plot and the treatments (Gill and Vijay Kumar, 1966).

WI $=\frac{\text { X }- \text { Y }}{\text { X }}$

Where:

$X=$ grain yield of weed free Plot

$\mathrm{Y}=$ grain yield of treatment

\section{Results and Discussion}

\section{Grain yield}

Weed management practices and establishment techniques significantly increased the grain and straw yields of rice as compared to that achieved in control plots. Among the weed management treatments, highest grain and straw yield of rice was recorded in the treatment mechanical hoeing using conoweeder twice which was statistically at par with fenoxaprop-p-ethyl (Puma super) @ 0.06kg a.i ha ${ }^{-1}+1 \mathrm{HW}$ at 30 DAT, metsulfuron methyl + chlorimuron 
ethyl (Almix) @ $0.004 \mathrm{~kg}$ a.i ha ${ }^{-1}+1 \mathrm{HW}$ at 30 DAT and fenoxaprop-p-ethyl (Puma super) @ $0.06 \mathrm{~kg}$ a.i ha ${ }^{-1}$ which were significantly superior to control and other treatments (Table 1). The possible reason for the better performance of these treatments in terms of grain and straw yield could be attributed to better expression of their yield attributes due to better management practices and reduction in crop- weed competition, resulting in significant reduction in dry weight and weed population.

The results are in close conformity to those given by Singh et al., (2003). Lowest grain yield of rice was recorded in treatment where only metsulfuron methyl + chlorimuron ethyl (Almix) @ 0.004 kg a.i ha ${ }^{-1}$ was applied. This might be due to inefficiency to control the heavily infested grassy weeds. However, under establishment methods, statistically non-significant results were observed in the grain and straw yields of both the conventional and SRI methods of establishment, but slight higher values were recorded under conventional method. This is in conformity with the results of Latif et al., (2004) and Dixit et al., (2007).

The highest and lowest harvest index values were recorded in weed free and weedy check plots, respectively during both the crop seasons (Table 1). However, under weed management practices, no significant difference with respect to harvest index was recorded among the different herbicide treatments.

This may be attributed to significant control of mixed weed flora due to application of these herbicides which reduced the weed dry matter production by weeds, thereby shifting the competition in favor of rice crop, thus increasing photosynthesis and better translocation of photosynthates to the sink during reproductive phase. Likewise, establishment techniques did not bring about any significant changes in harvest index of rice.

The lowest weed index was recorded in treatment where mechanical hoeing was done and in fenoxaprop-p-ethyl (Puma super) @ $0.06 \mathrm{~kg} \mathrm{a.i} \mathrm{ha}{ }^{-1}+1 \mathrm{HW}$ treatment. The lower weed index values might be due to lower weed population and weed dry weight as a result of maximum weed control efficiency (Table 1).

\section{Weed control efficiency}

Maximum weed control efficiency among the weed management practices was observed in treatment where mechanical hoeing using cono weeder twice was practiced followed by fenoxaprop-p-ethyl (Puma super) @ 0.06kg a.i $\mathrm{ha}^{-1}+1 \mathrm{HW}$ at $30 \mathrm{DAT}$, metsulfuron methyl + chlorimuron ethyl (Almix) @ 0.004 $\mathrm{kg}$ a.i ha ${ }^{-1}, 20 \mathrm{DAT}+1 \mathrm{HW}$ at $30 \mathrm{DAT}$, fenoxaprop-p-ethyl (Puma super) @ 0.06kg a.i ha ${ }^{-1}, 20$ DAT and metsulfuron methyl + chlorimuron ethyl (Almix) @ 0.004 kg a.i ha $^{-1}, 20$ DAT (Fig. 1).

This might be attributed to the control of all categories of weeds viz., grasses, sedges and broad leaved weeds with the application of these herbicides which reduced their dry weight than other treatments in comparison during both the crop seasons.

However, fenoxaprop-p-ethyl (Puma super) @ $0.06 \mathrm{~kg}$ a.i ha ${ }^{-1}$ was found to be more effective than metsulfuron methyl + chlorimuron ethyl (Almix) @ 0.004 kg a.i ha ${ }^{-1}$ in controlling the grassy weeds and sedges, but metsulfuron methyl + chlorimuron ethyl (Almix) @ 0.004 kg a.i ha ${ }^{-1}$ failed to control major grassy weeds, the infestation of which was more in the experimental field. These findings are in conformity with findings of Sadana and Velayutham (2012). 
Table.1 Effect of weed management practices and establishment techniques on grain yield, straw yield, harvest index and weed index of rice

\begin{tabular}{|c|c|c|c|c|c|c|c|c|c|c|c|c|}
\hline \multirow[t]{2}{*}{ Treatments } & \multicolumn{2}{|c|}{$\begin{array}{c}\text { Grain } \\
\text { Yield }\left(\text { qha }^{-1}\right)\end{array}$} & \multirow[t]{2}{*}{ Mean } & \multicolumn{2}{|c|}{ Straw Yield } & \multirow[t]{2}{*}{ Mean } & \multicolumn{2}{|c|}{$\begin{array}{c}\text { Harvest index } \\
(\%)\end{array}$} & \multirow[t]{2}{*}{ Mean } & \multicolumn{2}{|c|}{$\begin{array}{l}\text { Weed Index } \\
(\%)\end{array}$} & \multirow[t]{2}{*}{ Mean } \\
\hline & 2006 & 2007 & & 2006 & 2007 & & 2006 & 2007 & & 2006 & 2007 & \\
\hline \multicolumn{13}{|l|}{ Weed Management } \\
\hline Weedy Check & 30.75 & 31.45 & 31.10 & 44.65 & 46.26 & 45.46 & 40.78 & 40.49 & 40.64 & 34.04 & 33.71 & 33.86 \\
\hline Weed Free & 46.62 & 47.25 & 46.96 & 58.19 & 60.76 & 59.78 & 44.48 & 43.88 & 44.18 & 0.00 & 0.00 & 0.00 \\
\hline $\begin{array}{l}\text { Almix (Chlorimuron + MSM) @ } \\
0.004 \mathrm{~kg} \text { a.i ha }{ }^{-1}(20 \text { DAT) }\end{array}$ & 37.00 & 38.18 & 37.59 & 50.66 & 53.03 & 51.85 & 42.18 & 43.07 & 42.63 & 20.63 & 19.53 & 20.08 \\
\hline $\begin{array}{l}\text { Almix (Chlorimuron + MSM) @ } \\
0.004 \mathrm{~kg} \text { a.i ha }{ }^{-1}(20 \mathrm{DAT})+1 \mathrm{H} . \mathrm{W} \text { at } \\
30 \text { DAT }\end{array}$ & 40.54 & 41.66 & 41.10 & 51.43 & 53.56 & 52.50 & 44.36 & 43.63 & 43.10 & 13.04 & 12.20 & 12.62 \\
\hline $\begin{array}{l}\text { Fenoxaprop@0.06 kg a.i ha }{ }^{-1}(20 \\
\text { DAT }\end{array}$ & 39.83 & 40.87 & 40.35 & 50.83 & 53.43 & 52.13 & 43.67 & 43.33 & 43.15 & 14.56 & 13.87 & 14.22 \\
\hline $\begin{array}{l}\text { Fenoxaprop @ } 0.06 \mathrm{~kg} \text { a.i ha }{ }^{-1}(20 \\
\text { DAT })+1 \mathrm{H} . \mathrm{W} \text { at } 30 \text { DAT }\end{array}$ & 41.5 & 42.68 & 42.09 & 52.48 & 56.50 & 54.50 & 44.15 & 43.32 & 43.74 & 10.98 & 10.05 & 10.52 \\
\hline $\begin{array}{l}\text { Mechanical hoeing with Cono-weeder } \\
\text { at } 15 \text { and } 30 \text { DAT }\end{array}$ & 42.56 & 43.93 & 43.25 & 53.81 & 57.44 & 55.63 & 44.16 & 43.64 & 43.90 & 8.70 & 7.41 & 8.06 \\
\hline $\mathrm{CD}(p=0.05)$ & 3.46 & 3.16 & -- & 3.25 & 3.46 & -- & NS & NS & -- & -- & -- & -- \\
\hline \multicolumn{13}{|l|}{ Establishment Techniques } \\
\hline $\begin{array}{l}\text { Conventional transplanting ( } 27 \text { days } \\
\text { old seedlings and } 2-3 \text { seedlings hill }{ }^{-1} \text { ) }\end{array}$ & 39.92 & 41.09 & 40.51 & 51.68 & 54.21 & 52.95 & 43.47 & 43.15 & 43.31 & 14.37 & 13.40 & 13.89 \\
\hline $\begin{array}{l}\text { SRI (10 days old seedlings and } 1 \\
\text { seedling hill }{ }^{-1} \text { ) }\end{array}$ & 39.74 & 40.63 & 40.12 & 51.76 & 54.64 & 53.20 & 43.31 & 42.96 & 43.14 & 14.75 & 14.26 & 14.51 \\
\hline $\mathrm{CD}(p=0.05)$ & NS & NS & -- & NS & NS & -- & NS & NS & & -- & -- & -- \\
\hline
\end{tabular}


Table.2 Effect of weed management and establishment techniques on relative economics of rice

\begin{tabular}{|c|c|c|c|c|}
\hline Treatment & $\begin{array}{c}\text { Total cost of cultivation } \\
\left(\text { Rs. ha }{ }^{-1}\right)\end{array}$ & $\begin{array}{c}\text { Gross Returns } \\
(\text { Rs. ha.1) }\end{array}$ & $\begin{array}{l}\text { Net Returns } \\
\left(\text { Rs. } \text { ha }^{-1}\right)\end{array}$ & $\mathrm{B}: \mathrm{C}$ ratio \\
\hline \multicolumn{5}{|l|}{ Weed management } \\
\hline Weedy Check & 12387 & 27102 & 14715 & 1.19 \\
\hline Weed Free & 16587 & 40601 & 24014 & 1.45 \\
\hline Almix (Chlorimuron + MSM) @ $0.004 \mathrm{~kg} \mathrm{a.i} \mathrm{ha}{ }_{-1}^{-1}(20 \mathrm{DAT})$ & 12781 & 32598 & 19816 & 1.55 \\
\hline $\begin{array}{l}\text { Almix (Chlorimuron + MSM) @ } 0.004 \mathrm{~kg} \text { a.i ha }{ }^{-1} \text { (20DAT) } \\
+1 \mathrm{H} . \mathrm{W} \text { at } 30 \mathrm{DAT}\end{array}$ & 14181 & 35510 & 21328 & 1.50 \\
\hline Fenoxaprop @ $0.06 \mathrm{~kg}$ a.i ha ${ }_{-1}^{-1}(20 \mathrm{DAT}$ & 13656 & 34886 & 21229 & 1.55 \\
\hline $\begin{array}{l}\text { Fenoxaprop @ } 0.06 \mathrm{~kg} \text { a.i ha }(20 \mathrm{DAT})+1 \mathrm{H} . \mathrm{W} \text { at } 30 \\
\text { DAT }\end{array}$ & 15056 & 36239 & 21182 & 1.41 \\
\hline \multicolumn{4}{|l|}{ Establishment techniques } & 1.78 \\
\hline $\begin{array}{l}\text { Conventional transplanting ( } 27 \text { days old seedlings and 2-3 } \\
\text { seedlings hill }{ }^{-1} \text { ) }\end{array}$ & 13423 & 35030 & 21606 & 1.61 \\
\hline SRI ( 10 days old seedlings and 1 seedling hill $\left.{ }^{-1}\right)$ & 14601 & 34822 & 20220 & 1.38 \\
\hline
\end{tabular}

Table.3 Coefficient of correlation ( $\mathrm{r}$ ) between rice yield and various weed parameters at different growth stages

\begin{tabular}{|c|c|c|c|c|c|c|c|c|}
\hline & Rice yield & $\begin{array}{c}\text { WP at } 30 \\
\text { DAT }\end{array}$ & $\begin{array}{c}\text { WP at } 60 \\
\text { DAT }\end{array}$ & $\begin{array}{c}\text { WP at } 90 \\
\text { DAT }\end{array}$ & $\begin{array}{c}\text { WP at } \\
\text { harvest }\end{array}$ & $\begin{array}{c}\text { WDW at } \\
\text { 30DAT }\end{array}$ & WDW at 60DAT & $\begin{array}{l}\text { WDW at } \\
\text { 90DAT }\end{array}$ \\
\hline \multicolumn{9}{|l|}{ Rice yield } \\
\hline WP at 30 DAT & $-0.972 * *$ & & & & & & & \\
\hline WP at 60 DAT & $-0.972 * *$ & $0.998 * *$ & & & & & & \\
\hline WP at 90 DAT & $-0.971 * *$ & $0.997 * *$ & $0.995 * *$ & & & & & \\
\hline WP at harvest & $-0.920 * *$ & $0.915 * *$ & $0.913 * *$ & $0.935 * *$ & & & & \\
\hline WDW at 30 DAT & $-0.866^{* *}$ & $0.922 * *$ & $0.917 * *$ & $0.900 * *$ & $0.695 * *$ & & & \\
\hline WDW at 60 DAT & $-0.862 * *$ & $0.917 * *$ & $0.912 * *$ & $0.895 * *$ & $0.689 * *$ & $1.000 * *$ & & \\
\hline WDW at 90 DAT & $-0.853 * *$ & $0.908 * *$ & $0.903 * *$ & $0.885 * *$ & $0.672 * *$ & $0.999 * *$ & $0.999 * *$ & \\
\hline WDW at Harvest & $-0.859 * *$ & $0.915 * *$ & $0.910 * *$ & $0.893 * *$ & $0.683 * *$ & $0.999 * *$ & $1.000 * *$ & $1.000 * *$ \\
\hline
\end{tabular}

**significant at $1 \%$ *significant at $5 \% \mathrm{WP}$ - weed population WDW- weeds dry weight

DAT- Days after transplanting 
Fig.1 Effect of weed management practices and establishment techniques on weed control efficiency (\%) at 60 DAT and at harvest
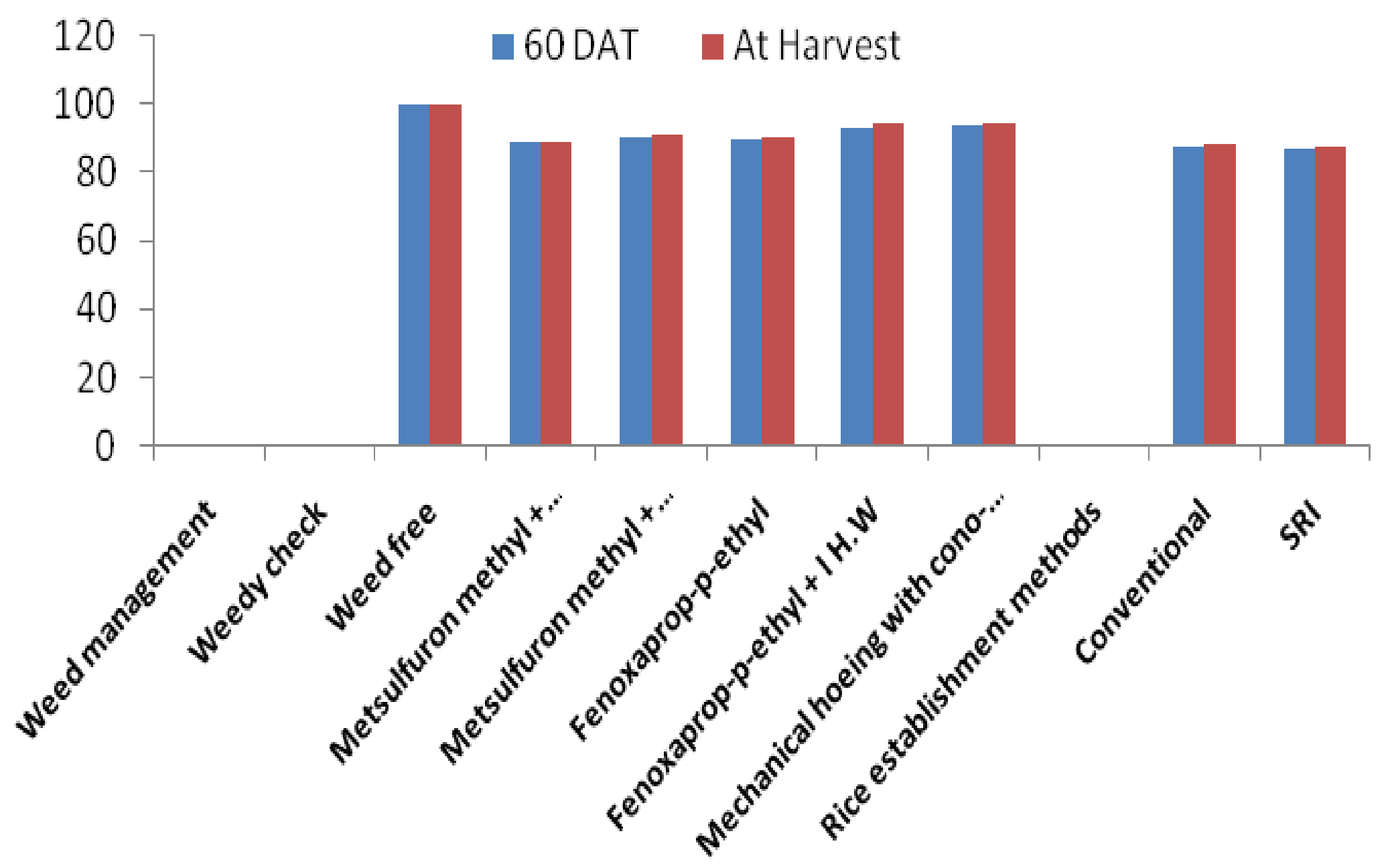


\section{Correlation studies}

Correlation between grain yield of rice and various weed parameters at different growth stages viz. 30, 60, 90 DAT and at harvest reveals that rice yield was significantly but negatively correlated to weed population as well as dry matter of weeds (Table 3 ). It was further observed that the coefficient of correlation ( $r$ ) values for weed population and dry matter were more during the initial stages of crop growth i.e., at $30 \quad(\mathrm{r}=-0.972 * *$ for weed population and $\mathrm{r}=-0.866^{* *}$ for dry matter) and $60 \quad(\mathrm{r}=-0.972 * *$ for weed population and $\mathrm{r}=-0.862 * *$ for dry matter) days after transplanting. The values of coefficient of correlation (r) were $-0.971 * *$ and $-0.920 * *$ at 90 days and at harvest for weed population, respectively. Similarly, the values of coefficient of correlation $(r)$ were $0.853 * *$ and $-0.859 * *$ for dry matter at 90 DAT and at harvest. It was further observed that all the weed parameters at different growth stages were having significantly positive correlation among them.

\section{Economics}

The net returns registered from rice were relatively higher in weed free treatment (Rs. $24014 \mathrm{ha}^{-1}$ ) closely followed by the treatment where mechanical hoeing was done (Rs. $23923 \mathrm{ha}^{-1}$ ) as compared to other treatments under weed management methods. Among the herbicidal treatments, metsulfuron methyl + chlorimuron ethyl (Almix) @ 0.004 kg a.i ha $^{-1}+1$ H.W (Rs. 21328 ha $^{-1}$ ) gave higher returns as compared to other herbicidal treatments. This can be assigned to higher grain and straw yield of rice as well as low cost of herbicide. Among the rice establishment methods, crop planted under conventional method registered more economic returns as compared to that planted under SRI method with the corresponding values of Rs. 21606 and Rs. 20220, respectively. Higher B:C ratio was observed with the mechanical hoeing using conoweeder twice (1.78) which was closely followed by metsulfuron methyl + chlorimuron ethyl (Almix)@ 0.004 kg a.i ha ${ }^{-1}$ and fenoxapropp-ethyl (Puma super) @ 0.06kg a.i ha ${ }^{-1}$ with the $\mathrm{B}: \mathrm{C}$ values of 1.55 and 1.55 , respectively (Table 2).

The results revealed the superiority of the treatment with respect to crop productivity where mechanical hoeing using cono-weeder twice was used as weed management practice which was statistically similar to other weed management treatments like fenoxaprop-pethyl (Puma super) @ 0.06kg a.i ha ${ }^{-1}+1 \mathrm{HW}$, metsulfuron methyl + chlorimuron ethyl (Almix) @ 0.004kg a.i ha ${ }^{-1}+1 \mathrm{HW}$ and fenoxaprop-p-ethyl when applied alone. Among the establishment methods of rice, statistically non-significant results were obtained with respect to grain yield, straw yield and harvest index in conventional and SRI methods of rice establishment. Mechanical hoeing with cono-weeder practised in rice proved to be superior economically as compared to all other weed management practices. Among the rice establishment methods, crop planted under conventional method registered more economic returns as compared to that planted under SRI method. Higher B:C ratio was observed with the mechanical hoeing using conoweeder twice (1.78) which was closely followed by metsulfuron methyl + chlorimuron ethyl (Almix) @ 0.004 kg a.i ha ${ }^{-1}$ and fenoxaprop-p-ethyl (Puma super) @ $0.06 \mathrm{~kg}$ a.i ha ${ }^{-1}$.

\section{References}

Ali Naiyar and Izhar Tajwar. 2017. Performance of SRI principles on growth, yield and profitability of rice (Oryza sativa L.). Journal of Pharmacognosy and Phytochemistry. 
6(5): 1355-1358

Anonymous, 1997. 'Bhat' Mahiti Pustika Kramank 1463. Deshmukh, K.V.,ed. Pune, India: Commissionarate of Agriculture, Maharashtra State. pp. 29

Dixit, A. K., Sharma, B. C., Bali, A. S. and Bazaya, B.R. 2007. Refinement of basmati rice establishment techniques for higher productivity and profitability and its impact on succeeding conventionally and zero tilled sown wheat crop. In: SRI India 2007. Second National Symposium on System of Rice Intensification (SRI) in India-Progress and Prospects October 3-5, 2007, Agartala, Tripura. pp. 118

Gill and Kumar, Vijay. 1966. Chemical weed control in onion. Indian Journal of Horticultural Sciences 29:53-58.

Latif, M. A., Ali, M. Y., Islam, M. R. and Rashid, M. H. 2004. Compilation Report on Extension of the System of rice Intensification $\mathrm{SRI}$ ) through verification. http:// ciifad. Cornel edu/ sri/wrrc/bd wrre.

Makarim, A.K., Balasubramanian, V., Zaini, Z., Syamsiah, I., Diratmadja, I.G.P.A., Handoko, Arfah., Wardana, I.P. and Gani, A. 2002. System of Rice intensification (SRI) evaluation of seedling age and selected components in Indonesia. In: SRI India 2007. Second National Symposium on System of Rice Intensification (SRI) in India-Progress and Prospects October 3-5, 2007, Agartala, Tripura. pp. 62-65

Purushamam, S. 1996. Competitive ability of weed flora in low land rice (Oryza sativa). Indian Journal of Agricultural Sciences 66: 70-72.

Sadana, R. Babar. and Velayutham, A. 2012. Weed management practices on weed characters, plant growth and yield of rice under system of rice intensification. Madras Agricultural Journal. 99(1-3): 46-50.

Singh, S., Singh, H., Narwal, S. and Malik, R. A. 2003. Performance of herbicides in transplanted rice. Indian Journal of Weed Science 35 (1\&2): 114-116. Gautam KC and Mishra JS. 1995. Problems, prospects and new approaches in weed management. Pesticides information 21: 7-19.

Uphoff, N. 2002. Changes and evaluation in SRI methods. In: Proceedings of International conference on assessments of SRI, April 1-4, Sanya, China. pp 8-14.

\section{How to cite this article:}

Jai Kumar, Anil Kumar, B.C. Sharma, Rajeev Bharat, A.P. Singh, Neetu Sharma Lobzang Stanzen and Reena. 2017. Effect of Weed Management Practices and Establishment Techniques on Yield and Economics of Rice in North-West Himalayan Sub-Tropical Foothills. Int.J.Curr.Microbiol.App.Sci. 6(12): 1714-1722. doi: https://doi.org/10.20546/ijcmas.2017.612.194 